\title{
Case Study: Alex Charter School
}

Gordon Johnson, California State University, Northridge, USA Raj Kiani, California State University, Northridge, USA

\begin{abstract}
This case discusses issues associated with charter schools. Topics include accounting, statistics, and economics. The focus is on profit planning and budgeting. Students will prepare an income statement, determine a break-even point for enrollment, contribution margin, elasticity of demand to assist in decision-making about tuition, averages, and a regression equation to estimate test scores, given class size. Finally, strategic thinking is required to write a conclusion.
\end{abstract}

\section{INTRODUCTION}

$\mathcal{B}$ ill Jensen was very unhappy with the quality of education his children received in public schools, so he started a private charter high school. In order to achieve his mission, he decided to become the principal of the Alex Charter School so he can reach his vision which will be one of the best private charter schools in the next five years. Bill Jensen is aware that by filling his vision, he can achieve his mission. As a school principal, he must make critical decisions following long-term strategic planning for each case as what to do, why to do it, and how to do it? As result of his effort, The Chamber of Commerce passed a resolution in support of the private school. He signed a lease for $\$ 3,500$ per month rent and hired 13 teachers who he thought were the best in the public schools. Each teacher earns $\$ 60,000$ per year. In addition, he hired three other employees, each earning $\$ 30,000$ per year. Each student paid $\$ 4,000$ per year tuition. Furthermore, additional cost for school activities is $\$ 1,000$ per student.

To maximize learning, class size is limited to 15 . To balance the budget, Bill had a fundraising program (organized by volunteers), including car washes and yard sales. Direct appeals to parents and homeowner associations were also part of the program. In 2009, he raised \$100,000.

The main objective of the case is to maintain its quality of education. In order to achieve this, the Alex Charter School has to have financial stability. To achieve this objective, Bill Jensen should apply profit planning or budgeting techniques to determine the relationship between revenues and related expenses and also a break-even point required to manage the school in an efficient manner. Furthermore, the manager can project the budgeted income statement and statement of cash flow for the next 12 months using a profit planning concept and making sure that they are financially sound.

\section{TOP 10 CONCEPTS}

- $\quad$ Financial Accounting: 1(a), 2

- $\quad$ Managerial Accounting: 1(b \&c),3,4,7

- $\quad$ Statistics: 1,4

- $\quad$ Microeconomics: 5

\section{REQUIREMENTS}

In this case, financial, statistical, and economic information are relevant and critical for the decision maker. Therefore, the following related questions are designed to provide relevant information about the case for the principal regarding school activities in 2009 and to help the principal project financial statements for the following year. 
1. Define :

a. Total revenue(sales) for 2009

b. Total costs for 2009 , break down the total costs into fixed and variable, and explain the fixed and variable costs behavior anyway. Then develop a cost equation model: $\mathrm{Y}=\mathrm{a}+\mathrm{b}(\mathrm{X})$ where $\mathrm{Y}=$ Total annual costs, $X=$ Total activity driver(number of students), $a=$ Total annual fixed costs, and $b=$ slope of the line(variable cost per student)

c. Contribution margin per student

2. Prepare an income statement for 2009.

3. What is the break-even point (number of students) without fundraising?

4. Research into similar private schools showed:

\begin{tabular}{|c|c|}
\hline Tuition & Enrollment \\
\hline$\$ 3,000$ & 300 \\
\hline$\$ 3,500$ & 230 \\
\hline$\$ 4,000$ & 200 \\
\hline$\$ 4,500$ & 170 \\
\hline$\$ 5,000$ & 120 \\
\hline
\end{tabular}

Find the elasticity of demand. Is demand elastic?

5. A sample of contributions in dollars is: 100, 10, 20,1000, 50, 25, 10, 20

a. What is the mean?

b. What is the median?

6. A sample of private schools showed:

\begin{tabular}{|c|c|}
\hline Class size & Test score \\
\hline 30 & 83 \\
\hline 20 & 88 \\
\hline 15 & 95 \\
\hline 25 & 78 \\
\hline 21 & 81 \\
\hline 18 & 94 \\
\hline 26 & 86 \\
\hline
\end{tabular}

a. Use Excel Data Analysis to obtain a regression equation to estimate test scores, given class size.

b. Interpret the slope (regression coefficient) for this problem.

c. Estimate the test score if class size is 13 .

d. Find coefficient of determination.

e. Interpret coefficient of determination for this problem.

f. Interpret the p-value for the regression coefficient. At the 5\% significance level, can you reject the hypothesis that there is no relationship between class size and test score?

7. Apply strategic thinking to this case. Include recommendations for raising tuition, increasing class size, and shifting focus of fundraising to a small number of large donors.

\section{Learning Objectives of Accounting Subjects Related to Alex Charter School Case}

The accounting subjects related to this case are:

1. Cost behavior analysis

2. Cost Volume Profit (CVP) or Break-even analysis

3. Income statement determination 
Following is a brief explanation for each subject.

\section{COST BEHAVIOR ANALYSIS}

Knowledge of cost behavior allows a manager to assess changes in costs that result from changes in business activity output. This allows a manager to examine the effects of choices that change activity. For example, if excess capacity exists, bids that at least cover variable costs may be totally appropriate. Knowing what costs are variable and what costs are fixed can help a manager make better bids and, ultimately, better business decisions.

Cost behavior is the way a cost changes in relation to changes in activity output. Generally, in terms of cost behavior, costs are frequently classified into fixed and variable for managerial decision-making purposes.

Fixed cost is a cost that does not change in total as output changes (i.e. total fixed cost remains constant, even if output changes); however, fixed cost decreases per unit as the output level rises and increases per unit as the activity output level falls.

Variable cost increases in total with an increase in output and decreases in total with a decrease in activity output; however, variable cost per unit remains constant per unit.

So, total costs $=$ total fixed costs + total variable costs, which can be explained as

Total costs $=($ total fixed costs $)+($ Variable rate $) *($ amount of activity output $)$, or

$\mathrm{Y}=\mathrm{a}+\mathrm{bX}$

where $\mathrm{Y}=$ Total costs, $\mathrm{a}=$ total fixed costs, $\mathrm{b}=$ Variable rate, and $\mathrm{X}=$ amount of activity output.

\section{Break-Even (CVP) Analysis}

Cost-volume-profit (CVP) analysis estimates how changes in costs (both fixed and variable), sales volume, and price affect a company's profit.

CVP analysis allows managers to focus on selling prices, volume, costs, profits, and sales mix. Many different "what-if" questions can be asked to assess the effect of changes in key variables on profits.

The units sold approach defines sales volume in terms of units of product and gives answers in these same terms. The unit contribution margin is needed to solve for the break-even units. The sales revenue approach defines sales volume in terms of revenues and provides answers in these same terms. The overall contribution margin ratio can be used to solve for the break-even sales dollars.

At the break-even point, all fixed costs are covered. Above the break-even point, only variable costs need to be covered. Thus, contribution margin per unit is profit per unit, provided that the unit selling price is greater than the unit variable cost (which it must be for break-even to be achieved).

Contribution margin $=$ Sales minus total variable cost, which is the amount available to cover fixed expenses and provide for a profit.

Following is a summary of important equations:

1. $\quad$ Sales revenue $=$ Price per unit $\mathrm{X}$ Units sold

2. Net operating income $=$ Sales revenue - total variable cost- total fixed cost

3. Contribution margin per unit $=$ Price per unit - Variable cost per unit

4. Break-even point in units $=($ Total fixed costs $) /($ Contribution margin per unit $)$

5. Break-even point in Sales dollars= (Break-even point in units $) *($ Price per unit $)$ 


\section{How to prepare Income Statement}

Generally, for decision-making and control purposes, management prefers to use a variable costing income statement, which is known as a contribution margin income statement. The format is as follows:

Sales revenue

Less: Total variable costs

Contribution Margin

Less: Total fixed costs

Net Operating Income (loss)

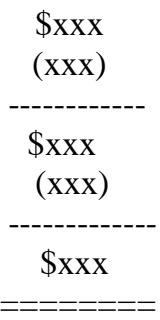

\$xxx

$\$ \mathrm{xxx}$

\$xxx

The answers to accounting and statistics questions related to Alex Charter School are:

A. Revenue for 2009 generated from students tuitions $=(\$ 4,000 \text { tuition per year per student })^{*}(\mathrm{x}=195)$ $=\$ 780,000$

where $X=$ number of students $=(13$ classes $) *(15$ students per class $)=195$

Additional revenue generated by donations $=\$ 100,000$

Therefore, Total revenue $=$ sales $=\$ 780,000+\$ 100,000=\$ 880,000$.

B. Total costs for $2009=$ total fixed costs + total variable costs

$\mathrm{Y}=\mathrm{a}+\mathrm{bX}=\$ 912,000+(\$ 1,000)(195)$

$=\$ 912,000+195,000=1,107,000$

where Total fixed costs for $2009=\mathrm{a}=$ (annual rent expenses + annual salaries for 13 teachers + annual salaries for 3 employees)

$$
\begin{aligned}
& =(\$ 3,500 * 12)+(13 * \$ 60,000)+(3 * \$ 30,000) \\
& =\$ 42,000+\$ 780,000+\$ 90,000=\$ 912,000
\end{aligned}
$$

Total variable costs $=($ additional cost for school activities pre student $) *(\#$ of Students $)=$

$$
\mathrm{Bx}=(\$ 1,000) *(195 \text { students })=\$ 195,000
$$

Generally, in terms of behavior, costs are frequently divided into two categories - variable and fixed.

\section{Variable Costs}

Variable cost behavior can be summarized as follows:

Total variable cost increases and decreases in proportion to changes in activity; however, variable cost per unit remains constant per unit.

\section{Fixed Costs}

Fixed cost behavior can be summarized as follows:

Total fixed cost is not affected by changes in activity (i.e., total fixed cost remains constant, even if activity changes); however, fixed cost decreases per unit as the activity level rises and increases per unit as the activity level falls.

C. Contribution Margin $=$ Revenue (sales) - Total variable costs 


\section{The Contribution Margin Income Statement}

\section{Percentage}

Sales revenue

Less: Total variable costs

Total contribution margin

Less: Total fixed costs

Net operating income (loss)

\begin{tabular}{|c|c|c|}
\hline $\begin{array}{l}\$ x x x \\
(x x x)\end{array}$ & $\begin{array}{r}\$ 880,000 \\
(195,000)\end{array}$ & $\begin{array}{l}100 \% \\
(22)\end{array}$ \\
\hline $\begin{array}{l}\text { \$xxx } \\
(\mathrm{xxx})\end{array}$ & $\begin{array}{l}\$ 685,000 \\
(912,000)\end{array}$ & $\begin{array}{l}78 \% \\
(104)\end{array}$ \\
\hline$\$ x x x$ & $(\$ 227,000)$ & $6 \%)$ \\
\hline
\end{tabular}

Generally, the decision maker prefers to use the Contribution Margin Income Statement for managerial decision-making rather than the traditional income statement format used for external financial reporting.

D. Break-even point $=($ total fixed costs $) /($ contribution margin per unit $)$

$$
\frac{\$ 912,000}{(\$ 4,000-1,000)}=304 \text { students }
$$

Contribution margin per student $=(\$ 4,000$ tuition per student $-\$ 1,000$ additional cost for school activities per student) $=\$ 3,000$.

At the break-even point, always revenue (sales) = total costs; that is, business does not make or lose money.

\section{RECOMMENDATIONS}

In case of the Alex Charter School, in order to maintain a break-even point, they must increase the student body by 109 (304 students at break-even point -195 students as planned).To achieve this goal, they must increase the class size to 23 students per teacher or increase the tuition to $\$ 5,677$ and maintain the same class size; that is, 15 students per teacher. Both options will balance the budget and it will be at the break-even point. Following are the income statements using either option:

\section{The Contribution Margin Income Statement}

\begin{tabular}{|c|c|c|}
\hline Price & Quantity & Elasticity \\
\hline 3000 & 300 & $.26 / .15=1.7$ \\
\hline 350 & 230 & $.14 / .13=1$. \\
\hline 400 & 200 & $.16 / .12=1.3$ \\
\hline 4500 & 170 & $.35 / .105$ \\
\hline
\end{tabular}

\begin{tabular}{lcccc} 
& Option (1) 304Students & \multicolumn{2}{c}{ Option (2) \$5,677 Tuition } \\
\hline Sales revenue & $304 * 4,000$ & $\$ 1,216,000$ & $195 * 5,677$ & $\$ 1,107,000$ \\
Less: Total variable costs & $\$ 1,000 * 304$ & $(304,000)$ & $195 * 1,000$ & $(195,000)$ \\
& ---------- & & -- \\
Total contribution margin & $\$ 912,000$ & & $\$ 912,000$ \\
Less: Total fixed costs & $(912,000)$ & & $(912,000)$ \\
& ---------- & & $-\$ 0.00$ \\
Net operating income (loss) & $\$ 0.00$ & & $======$
\end{tabular}

\section{Q3: Elasticity}


Demand is elastic, so an increase in tuition may NOT increase total revenue.

\section{Q4: Descriptive Statistics}

Mean $=1235 / 8=\$ 154$

Median $=$ mid point of 20 and $25=\$ 22.50$ than median.

The large donor pushes the man up to $\$ 154$, but the typical contributor, less than $\$ 30$; mean much larger

\section{Q5: Regression and Correlation}

1. $\quad \mathrm{y}=106.3-0.9 \mathrm{x}, \mathrm{x}=$ class size and $\mathrm{y}=$ test score

2. For each additional student in class, the test score decreases by 0.9 - almost one point.

3. $\quad \mathrm{Y}=106.3-.9(13)=95$

4. $\quad$ Coefficient of determination $=.52$

5. $53 \%$ of total variation in test score can be explained by variation in class size

6. Since the p-value for the regression coefficient is .0675>.05, there is more than a $5 \%$ probability that you would get a slope at least this large if there were no true relationship between class size and test score. You cannot reject the hypothesis that the population parameter slope is zero.

\section{Q6: Strategy}

1. Raising tuition is unlikely to increase profits.

2. Increasing class size will lower test scores.

3. Focus on wealthy contributors.

\section{CONCLUSIONS FOR ALEX CHARTER SCHOOL}

The main objective of Alex Charter School is to provide and prepare students with a high quality of education. To achieve this objective, the School must balance its budget. The school is not currently profitable. Therefore, the decision makers for the School would need to increase the number of students more than 50\%, which implies larger class sizes. However test scores will decrease if class size increases. Raising tuition will decrease total revenue due to elastic demand. The best alternative is to get large donations from wealthy contributors to balance the budget and therefore, maintain its quality of education.

\section{AUTHOR INFORMATION}

Gordon Johnson is Professor of Systems and Operations Management at California State University, Northridge. $\mathrm{He}$ has a Ph.D. from the University of Wisconsin in Quantitative Business Analysis, and has published in Management Science, Journal of Education for Business, Journal of the International Academy For Case Studies, and The Journal of Operations Management. He was Program Chair for the 1978 INFORMS National Meeting.

Raj Kiani is Professor of Accounting at California State University, Northridge, California. He has a Ph.D. from the University of Oklahoma, Norman, Oklahoma in Accounting, and has published in Journal of Accounting Review, Journal of International Taxation, the Tax Adviser, AICPA, International Business and Economics Research Journal, Journal of Business Economics Research, The Journal of American Academy of Business, Cambridge, Review of Business Research, and Applied Business Research. 